Prepared in cooperation with the National Park Service

\title{
Assessing Native Fish Restoration Potential in Catoctin Mountain Park
}

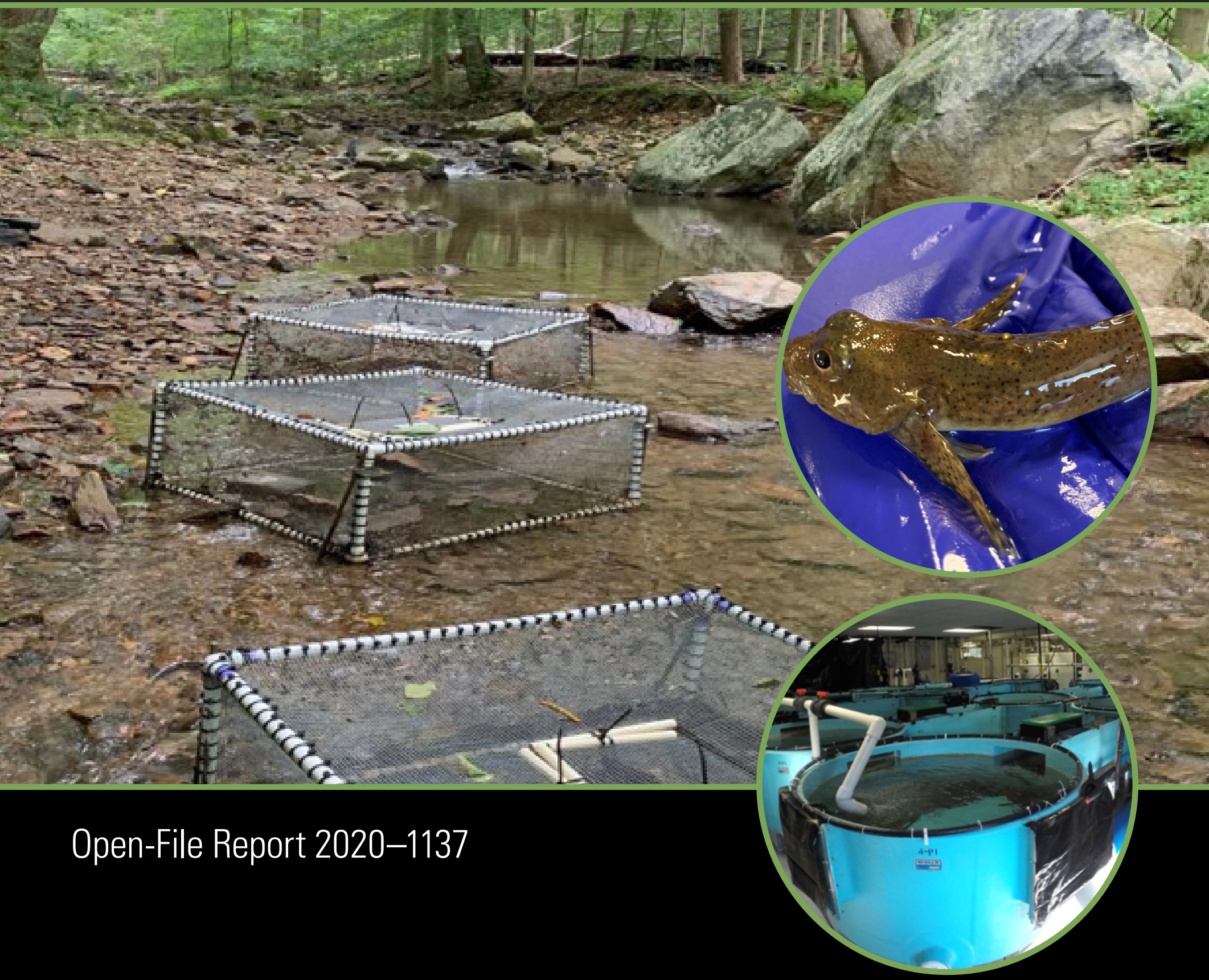

U.S. Department of the Interior U.S. Geological Survey 
Caption: Experimental fish enclosure placement in Catoctin Mountain Park, Maryland. Experimental Stream Laboratory at the U.S. Geological Survey at the Leetown Science Center in Kearneysville, West Virginia (bottom circle). Blue Ridge sculpin (Cottus caeruleomentum) (top circle). Photographs by N.P. Hitt, U.S. Geological Survey. 


\section{Assessing Native Fish Restoration Potential in Catoctin Mountain Park}

By Nathaniel P. Hitt, Karmann G. Kessler, Zachary A. Kelly, Karli M. Rogers, Hannah E. Macmillan, and Heather L. Walsh

Prepared in cooperation with the National Park Service

Open-File Report 2020-1137 


\title{
U.S. Department of the Interior \\ DAVID BERNHARDT, Secretary
}

\author{
U.S. Geological Survey \\ James F. Reilly II, Director
}

U.S. Geological Survey, Reston, Virginia: 2020

For more information on the USGS - the Federal source for science about the Earth, its natural and living resources, natural hazards, and the environment—visit https://www.usgs.gov or call 1-888-ASK-USGS.

For an overview of USGS information products, including maps, imagery, and publications, visit https://store.usgs.gov/.

Any use of trade, firm, or product names is for descriptive purposes only and does not imply endorsement by the U.S. Government.

Although this information product, for the most part, is in the public domain, it also may contain copyrighted materials as noted in the text. Permission to reproduce copyrighted items must be secured from the copyright owner.

Suggested citation:

Hitt, N.P., Kessler, K.G., Kelly, Z.A., Rogers, K.M., Macmillan, H.E., and Walsh, H.L., 2020, Assessing native fish restoration potential in Catoctin Mountain Park: U.S. Geological Survey Open-File Report 2020-1137, 17 p., https://doi.org/10.3133/ofr20201137.

Associated data for this publication:

Hitt, N.P., Kessler, K., Rogers, K., Macmillan, H., and Walsh, H., 2020, Stream temperature and sculpin growth data collected from Catoctin Mountain Park in 2019: U.S. Geological Survey data release,

https://doi.org/10.5066/P950A13P.

ISSN 2331-1258 (online) 


\section{Acknowledgments}

We thank Steve Faulkner, Tom O'Connell, Andrea Ostroff, Craig Snyder, Evan Rodway, Joe Dehnert, Vicki Blazer, Christine Densmore (U.S. Geological Survey), Lindsey Donaldson, Becky Loncosky, Rick Slade, Diane Pavek (National Park Service), John Mullican, Josh Henesy, Michael Kashiwagi, and Barbara Johnston (Maryland Department of Natural Resources) for assistance with this research. Research protocols were approved by the U.S. Geological Survey Leetown Science Center Institutional Animal Care and Use Committee (AEL-2019-001). Funding was provided by the FY19 Natural Resources Preservation Program. 



\section{Contents}

Acknowledgments ……...................................................................................................................

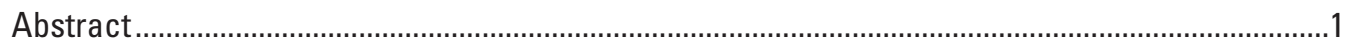

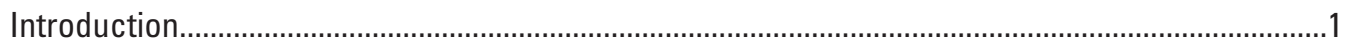

Methods

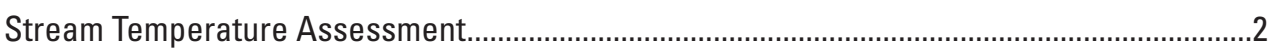

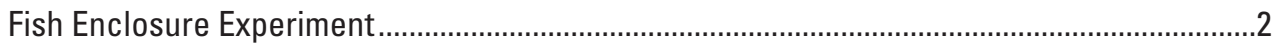

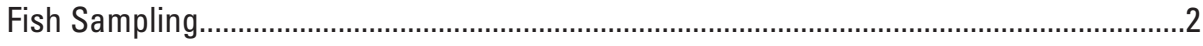

Histopathology and Fish Health Screening ..................................................................

Experimental Design .....................................................................................................

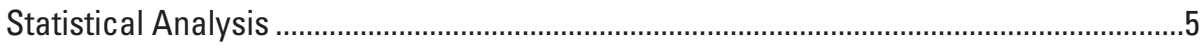

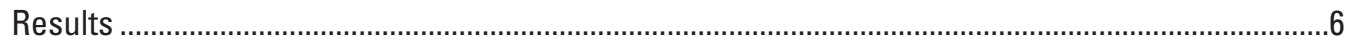

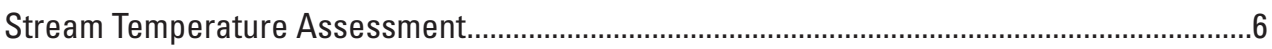

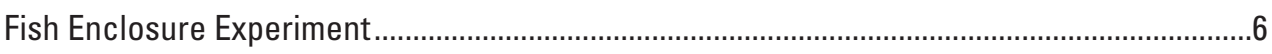

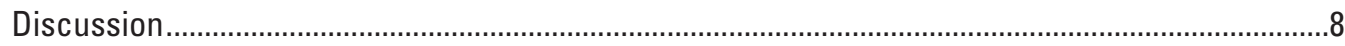

References Cited.............................................................................................................

Appendix 1 Hourly Stream Temperature Plots ..........................................................................14

\section{Figures}

1. Study site locations within Catoctin Mountain Park. .........................................................

2. Example of experimental fish enclosure placement in Owens Creek ...............................5

3. Hourly stream temperatures for the warmest site and coolest site during summer 2019............................................................................................................

4. Daily mean stream temperatures averaged across sites within Owens Creek, upper Big Hunting Creek, Blue Blazes Creek, and lower Big Hunting Creek ....................9

\section{Tables}

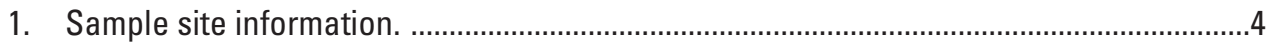

2. Summary of hourly stream temperatures during the 100 -day sample period ...................6

3. Comparison of daily mean temperatures within Owens Creek, upper Big Hunting Creek, Blue Blazes Creek, and lower Big Hunting Creek.....................................8

4. Relative abundance of fish in three spatially consecutive 100-m sampling areas within Owens Creek ....................................................................................................

5. Site-level summaries for fish growth and exposure temperatures for the caged-fish experiment.................................................................................................. 10

6. Summary of fitted linear mixed models for specific growth rate from the caged fish experiment. 


\section{Conversion Factors}

U.S. customary units to International System of Units

\begin{tabular}{|c|c|c|}
\hline Multiply & By & To obtain \\
\hline \multicolumn{3}{|c|}{ Length } \\
\hline inch (in.) & 2.54 & centimeter $(\mathrm{cm})$ \\
\hline inch (in.) & 25.4 & millimeter (mm) \\
\hline foot $(\mathrm{ft})$ & 0.3048 & meter $(\mathrm{m})$ \\
\hline yard (yd) & 0.9144 & meter $(\mathrm{m})$ \\
\hline \multicolumn{3}{|c|}{ Area } \\
\hline acre & 0.4047 & hectare (ha) \\
\hline \multicolumn{3}{|c|}{ Mass } \\
\hline ounce, avoirdupois (oz) & 28.35 & $\operatorname{gram}(\mathrm{g})$ \\
\hline
\end{tabular}

International System of Units to U.S. customary units

\begin{tabular}{|c|c|c|}
\hline Multiply & By & To obtain \\
\hline \multicolumn{3}{|c|}{ Length } \\
\hline millimeter $(\mathrm{mm})$ & 0.03937 & inch (in.) \\
\hline meter (m) & 3.281 & foot $(\mathrm{ft})$ \\
\hline kilometer (km) & 0.6214 & mile (mi) \\
\hline meter $(\mathrm{m})$ & 1.094 & yard (yd) \\
\hline \multicolumn{3}{|c|}{ Area } \\
\hline hectare (ha) & 2.471 & acre \\
\hline \multicolumn{3}{|c|}{ Mass } \\
\hline $\operatorname{gram}(\mathrm{g})$ & 0.03527 & ounce, avoirdupois (oz) \\
\hline
\end{tabular}

Temperature in degrees Celsius $\left({ }^{\circ} \mathrm{C}\right)$ may be converted to degrees Fahrenheit $\left({ }^{\circ} \mathrm{F}\right)$ as follows: ${ }^{\circ} \mathrm{F}$ $=\left(1.8 \times{ }^{\circ} \mathrm{C}\right)+32$.

Temperature in degrees Fahrenheit $\left({ }^{\circ} \mathrm{F}\right)$ may be converted to degrees Celsius $\left({ }^{\circ} \mathrm{C}\right)$ as follows: ${ }^{\circ} \mathrm{C}$ $=\left({ }^{\circ} \mathrm{F}-32\right) / 1.8$.

\section{Datum}

Vertical coordinate information is referenced to the North American Vertical Datum of 1988 (NAVD 88).

Horizontal coordinate information is referenced to the North American Datum of 1983 (NAD 83).

Altitude, as used in this report, refers to distance above the vertical datum. 


\section{Abbreviations}

$\begin{array}{ll}\text { AIC } & \text { Akaike information criterion } \\ \text { ANOVA } & \text { analysis of variance } \\ \text { CATO } & \text { Catoctin Mountain Park } \\ \text { CI } & \text { confidence intervals } \\ \text { DD20 } & \text { Degree-days above } 20^{\circ} \mathrm{C} \\ \text { MD-DNR } & \text { Maryland Department of Natural Resources } \\ \text { MDT } & \text { mean daily temperature } \\ \text { MWAT } & \text { maximum weekly average temperature } \\ \text { NOAA } & \text { National Oceanic and Atmospheric Administration } \\ \text { SGR } & \text { specific growth rate } \\ \text { USGS } & \text { U.S. Geological Survey }\end{array}$





\title{
Assessing Native Fish Restoration Potential in Catoctin Mountain Park
}

\author{
By Nathaniel P. Hitt, Karmann G. Kessler, Zachary A. Kelly, Karli M. Rogers, Hannah E. Macmillan, and \\ Heather L. Walsh
}

\section{Abstract}

Biological conservation is a fundamental purpose of the National Park system, and Catoctin Mountain Park (CATO) supports high-quality habitat for native fishes in the headwaters of the Chesapeake Bay watershed in eastern North America. However, native Blue Ridge sculpin (Cottus caeruleomentum) have been extirpated in Big Hunting Creek above Cunningham Falls in CATO. Prior research indicates that infection by the fungal-like protist Dermocystidium is a likely cause for the extirpation, but elevated stream temperatures also have been observed in the study area, and it remains unknown whether thermal stress may exacerbate infections or otherwise limit habitat suitability for fishes in CATO.

The purpose of this study was to quantify spatial variation in summer stream temperatures and to evaluate the effects of temperature on sculpin growth rates and susceptibility to Dermocystidium infection. We used observational and experimental methods to address these objectives. First, we deployed stream temperature gages at 10 sites throughout the study area to assess hourly and daily temperatures during the summer of 2019. Second, we conducted an in situ fish enclosure experiment at five of the temperature sites to assess fish growth and susceptibility to Dermocystidium infection over a 45-day exposure period. For this experiment we collected sculpin from a stream in CATO that supports a robust population of Blue Ridge sculpin (Owens Creek) and held them in quarantine for 50 days in the Experimental Stream Laboratory at the U.S. Geological Survey (USGS) Leetown Science Center. Pre-exposure histopathology confirmed the absence of Dermocystidium infection prior to the introduction of fish into experimental enclosures.

We found that stream temperatures were warmer where sculpin have been extirpated than elsewhere in CATO where sculpin persist. However, the fish enclosure experiment revealed a positive effect of temperature on fish growth, suggesting that increased food availability and foraging rates compensated for increased metabolic demands in the warmest sites. Moreover, fish held in enclosures did not develop Dermocystidium infection. Our results therefore suggest that current environmental conditions in upper Big Hunting Creek may be suitable for Blue Ridge sculpin reintroduction, and this could ultimately lead to sportfishing opportunities by increasing the forage base for native brook trout (Salvelinus fontinalis).

\section{Introduction}

Native species conservation is a fundamental purpose of the National Park system within the U.S. Department of the Interior as established by the Organic Act of 1916. Catoctin Mountain Park (CATO) in central Maryland supports a prized trout fishery and a healthy community of native fishes (Hitt and others, 2017a) with one exception: native Blue Ridge sculpin (Cottus caeruleomentum; Kinzinger and others, 2000) appear to have been extirpated from Big Hunting Creek above Cunningham Falls. Infection by a fungal-like protist Dermocystidium sp. is hypothesized to have facilitated the extirpation (Blazer and others, 2016), and such infections have been linked to fish population declines elsewhere (Rowley and others, 2013). However, elevated stream temperatures in the study area (Hitt and others, 2017a) also may be an underlying cause, either as a direct physiological effect or by exacerbating infection rates (Kocan and others, 2009; Karvonen and others, 2010). Resource managers at CATO therefore, could benefit from understanding why this native species was extirpated and whether reintroduction is feasible.

We have high confidence that Blue Ridge sculpin have been extirpated from Big Hunting Creek above Cunningham Falls. Fish surveys in 2008 confirmed the species was present, but subsequent annual surveys by the U.S. Geological Survey (USGS) and Maryland Department of Natural Resources (MD-DNR) did not detect the target species despite intensive sampling effort (Blazer and others, 2016). Moreover, the high abundance of this species in nearby Owens Creek (Hitt and others, 2017a) and the effect of Cunningham Falls as a fish passage barrier also supports our assertion that sculpin have been extirpated from Big Hunting Creek above the waterfall.

Sculpin reintroduction may be particularly important for brook trout (Salvelinus fontinalis) conservation because sculpin are prey for large stream-dwelling trout (Meredith and others, 2014), and additional management actions are currently underway to enhance the population of brook trout in Hunting 
Creek through the manual removal of brown trout from upper Big Hunting Creek (M. Kashiwagi, MD-DNR, oral commun., August 17, 2019). Sculpin often have an important role in food webs and energy flows in stream ecosystems (Adams and Schmetterling, 2007) and they constitute a large component of the fish assemblage in nearby Owens Creek (Hitt and others, 2017a) that suggests their extirpation from upper Big Hunting Creek may substantially alter stream ecosystem structure and function.

\section{Methods}

\section{Stream Temperature Assessment}

We collected hourly stream temperature data from 10 sites between June 1 and September 9, 2019, (100 days) to observe maximum summer temperatures in the study area (fig. 1). Our stream temperature survey included three sites in Owens Creek, three sites in upper Big Hunting Creek (that is, above Cunningham Falls), two sites in lower Big Hunting Creek, and two sites in Blue Blazes Creek. We used Onset ProV2 and Tidbit water temperature gages, and both are rated to an accuracy of $\pm 0.02{ }^{\circ} \mathrm{C}$. Gages were secured within perforated polyvinyl chloride (PVC) cases and attached to rebar driven into substrates following Snyder and others (2015). We checked gage accuracy prior to deployment in water baths with controlled temperatures.

We calculated thermal summary statistics for each site and compared sites and streams using analysis of variance (ANOVA). We also calculated maximum weekly average temperature (MWAT) as an index of thermal habitat suitability for native brook trout because the species typically is absent when this measure exceeds $23.3{ }^{\circ} \mathrm{C}$ (Wehrly and others, 2007). MWAT was used previously by Snyder and others (2015) to forecast thermal habitat suitability for native brook trout in the Blue Ridge physiographic region where the study area is located. We used data from the summer sampling period (100 days) for all sites to evaluate brook trout habitat suitability and spatial trends. We also used a subset of the temperature data for fish cage sites during the exposure period to evaluate fish growth rates (see below).

To interpret water temperature patterns, we used precipitation records from a remote automatic weather station located at CATO (administered and maintained by the Western Regional Climate Center). We approximated the timing of designated "significant" rainfall events based on daily precipitation levels that exceeded the average daily precipitation during 2019 plus one standard deviation (13.4 millimeters per day). Using this criterion, the study period included 12 days with significant rainfall events and cumulatively composed a period of near-average precipitation based on long-term climate data (1895-2019) maintained by the National Oceanic and Atmospheric Administration (NOAA) (data not shown). In contrast, the study area during this time period experienced above-average air temperatures based on NOAA long-term climate data, and this pattern was observed across much of the eastern United States during summer 2019 (data not shown).

\section{Fish Enclosure Experiment}

The fish enclosure experiment consisted of four steps: (1) we collected Blue Ridge sculpin from a 300-meter (m) section of Owens Creek; (2) we quarantined fish at the Leetown Science Center for 50 days, during which time we conducted a histology analysis for a subset of individuals to confirm absence of Dermocystidium and other pathogens and parasites; (3) we moved disease-free fish to a series of wire-mesh cages in the study area for a 45-day exposure period; and (4) we evaluated individual growth and Dermocystidium infection status after the exposure period with respect to site location and stream temperatures during the exposure period.

\section{Fish Sampling}

We collected sculpin from Owens Creek on May 24, 2019, and June 7, 2019, using 1-pass backpack electrofishing methods (Reynolds and Kolz, 2012) for a total of three sequential 100-m sampling reaches. We enumerated all captured fish at the species level and returned all fish to the stream except for a subset of adult sculpin we retained for caged fish experiments. We observed many young-of-year (age-0) sculpin but did not count them in the fish survey nor include them in experimental collections. We transported collected fish to the USGS Leetown Science Center (LSC) in stream water with ice and bubblers to maintain temperature and dissolved oxygen levels.

We quarantined fish collected from Owens Creek at the LSC Experimental Stream Laboratory for 50 days (June 7 to July 26, 2019) following guidance from Maryland Department of Natural Resources (B. Johnston, MD-DNR, oral commun., November 29, 2018). Fish were maintained in a series of riffle chambers within recirculating channels supplied with particulate and ultraviolet (UV) filtration. Laboratory stream temperatures were held at approximately $13{ }^{\circ} \mathrm{C}$. Following a 1-week acclimation period, we injected a 12-millimeter ( $\mathrm{mm})$ passive integrated transponder tag ventrally in each fish to enable individual identification. We fed fish daily with frozen bloodworms at a rate of approximately 5 percent of fish biomass per day. As a biosecurity protocol to prevent introduction of novel pathogens or parasites into the environment, the LSC Experimental Stream Laboratory treats effluent water with a hypochlorite solution ( $>200$ milligrams per liter) following standard operating procedures and USGS Leetown Science Center Institutional Animal Care and Use Committee approval (protocol AEL-2019-001). 


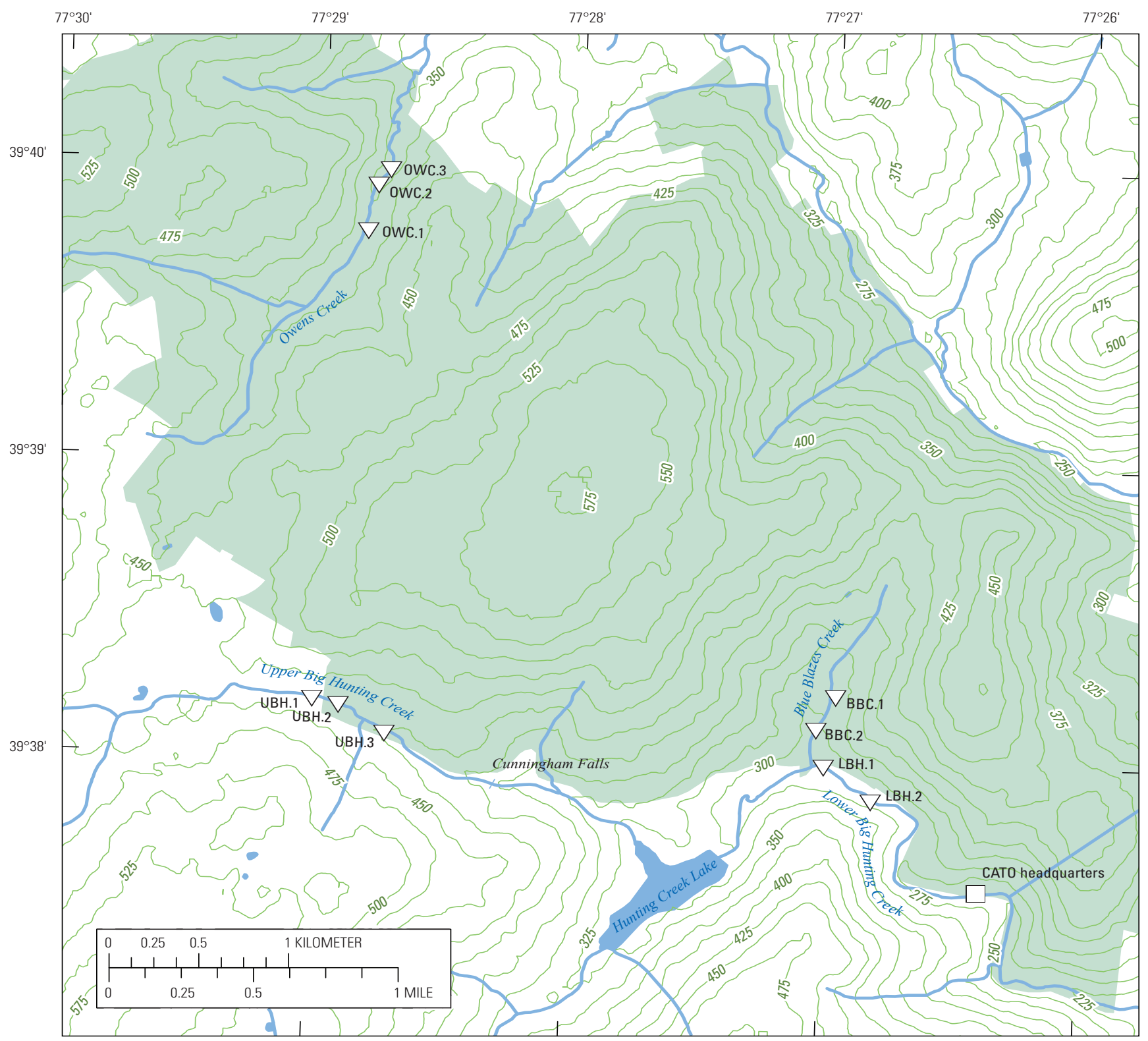

Base from ESRI, 2020
Hydrology from U.S. Geological Survey, National Hydrography Dataset, 2020 Hydrology from U.S. Geological Survey, National Hydrography D
Digital elevation data from U.S. Geological Survey, EROS, 2020 North American Datum of 1983, UTM Zone 18 North

EXPLANATION

Extent of Catoctin Mountain Park (CATO)
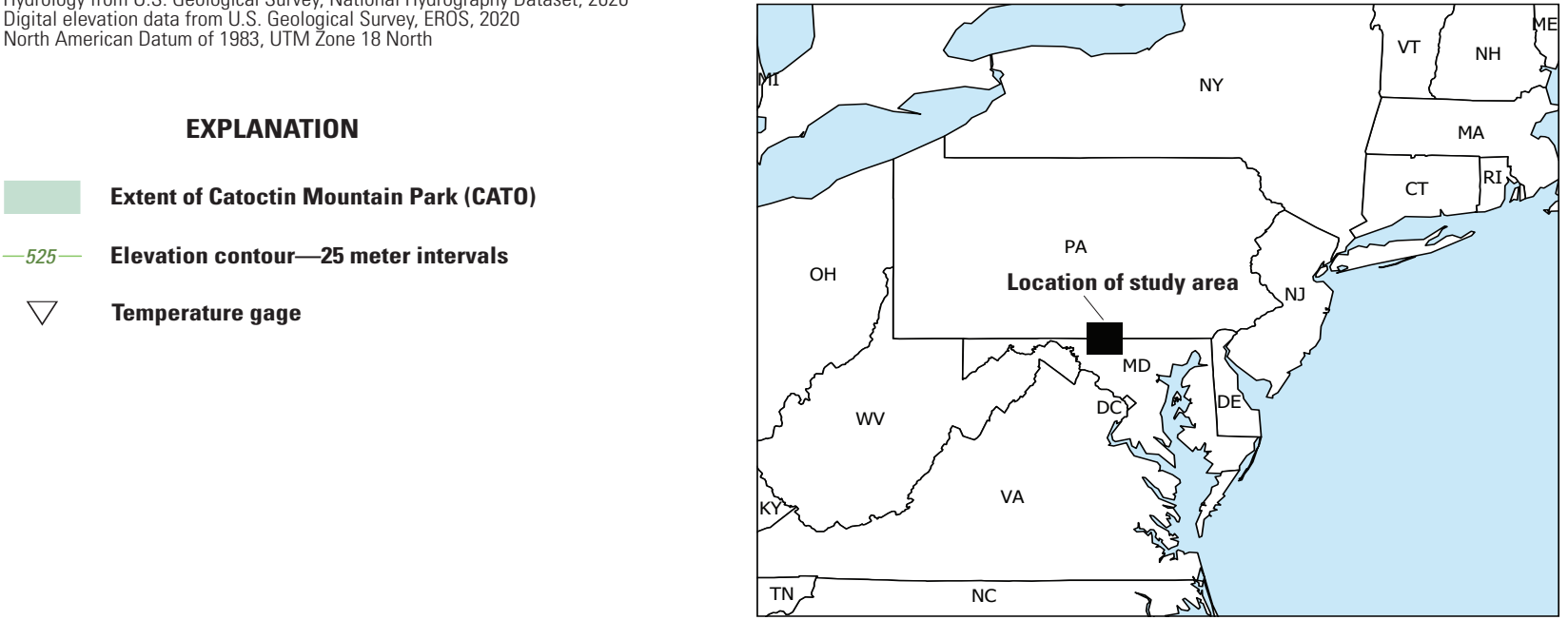

Figure 1. Study site locations within Catoctin Mountain Park (CATO). 


\section{Histopathology and Fish Health Screening}

We periodically inspected fish for external abnormalities (that is, Dermocystidium cysts, parasites, lesions) during the quarantine period, and we selected 10 individuals at random for pre-exposure histopathology analysis. Selected fish were euthanized with tricaine methanesulfonate (Tricaine-S, Syndel, Ferndale, Washington), slit ventrally, and placed in zincbuffered formalin (Z-Fix, Anatech, Battle Creek, Michigan) for $>48$ hours. Specimens were then decalcified in ethylenediamine tetraacetic tetrasodium salt dihydrate (EDTA; SigmaAldrich) at $\mathrm{pH} 7.2$ for 2-4 days. After decalcification, transverse sections of the body were embedded into paraffin blocks, sectioned at 5 micrometers, and stained with hematoxylin and eosin (Luna, 1992) for visual inspection with 4-60x magnification following Blazer and others (2016). Pre-exposure histology analysis confirmed the absence of Dermocystidium infection. We used the same methods for histological analysis for fish collected from enclosures after the exposure period (see below).

We also collected kidney and spleen samples for viral and bacterial assessment of the 10 fish used for pre-exposure histological analysis. This analysis was conducted by personnel at the Lamar National Fish Hatchery (U.S. Fish and Wildlife Service, Lamar, Pennsylvania) following standard methods of the American Fisheries Society (American Fisheries SocietyFish Health Section, 2016). Results indicated the absence of viral and bacterial targets and are catalogued as Case \#19-161 in the National Wild Fish Health Survey maintained by the U.S. Fish and Wildlife Service.

\section{Experimental Design}

We constructed 11 cages for use as experimental fish enclosures. Cages were constructed from PVC pipes ( 2.5 centimeter $[\mathrm{cm}]$ diameter) and $0.6 \mathrm{~cm}$ wire mesh and measured approximately $1 \mathrm{~m}$ by $1 \mathrm{~m}$ by $0.4 \mathrm{~m}$. We deployed cages in five sites (table 1) with two cages per site for all sites except for Owens Creek (OWC.3) where three cages were deployed. All cages were placed in riffle habitats and fixed to the stream bottom with rebar. We added natural substrates to the bottom of each cage and deployed cages $>7$ days prior to introducing fish to enable benthic macroinvertebrate colonization as a food source. We visited sites multiple times per week to remove leaves and woody debris from the exterior of cages. Similar cage designs and deployment strategies were used for sculpin research by Zimmerman and Vondracek (2006), and an example from our study is shown in figure 2 .

We randomly assigned 3 fish per cage for a total of 33 individuals. We introduced fish into cages on July 26, 2019 and removed them on September 9, 2019 (45 exposure days). We measured individual weights in situ on August 1 and September 9, yielding 39 days for growth analysis. However, for three individuals we measured initial weights on August 5, and for one individual we measured initial weight on August 9, yielding 35 and 31 days for growth analysis in those cases, respectively. We calculated specific growth rate (SGR) following Cook and others (2000) as

$$
S G R=\frac{\ln \left(W_{f}\right)-\ln \left(W_{i}\right)}{t} \times 100
$$

where

$$
\begin{aligned}
W_{f} & \text { is the final weight in grams; } \\
W_{i} & \text { is the initial weight in grams; and } \\
t & \text { is time in days. }
\end{aligned}
$$

This calculation expresses SGR as percent body weight gain per day. Sample size was reduced from 33 to 31 individuals for analysis owing to one likely mortality (OWC.3) and one escape (UBH.3). Fish cages were co-located with temperature sites except for LBH.2, in which cages were located $\sim 250 \mathrm{~m}$ downstream of the temperature gage.

Table 1. Sample site information. Site latitude and longitude are given in Universal Transverse Mercator zone 17N coordinates (NAD83 datum). Stream temperature was measured hourly in all sites. OWC, Owens Creek; UBH, upper Big Hunting Creek; BBC, Blue Blazes Creek; LBH, lower Big Hunting Creek; *, fish cage site.

\begin{tabular}{lllccc}
\hline Stream & Site code & Latitude & Longitude & $\begin{array}{c}\text { Elevation } \\
\text { (meters) }\end{array}$ & $\begin{array}{c}\text { Upstream basin area } \\
\text { (hectares) }\end{array}$ \\
\hline OWC & OWC.1 & 39.662757 & -77.480462 & 387 & 753.4 \\
& OWC.2 & 39.665322 & -77.479902 & 371 & 771.3 \\
& OWC.3* & 39.666235 & -77.479124 & 370 & 787.2 \\
\hline \multirow{2}{*}{ UBH } & UBH.1 & 39.636481 & -77.483223 & 437 & 641.1 \\
& UBH.2* & 39.636142 & -77.481513 & 431 & 663.8 \\
& UBH.3* & 39.634602 & -77.478495 & 425 & 787.6 \\
\hline BBC & BBC. ${ }^{*}$ & 39.637175 & -77.449296 & 309 & 146.4 \\
& BBC.2 & 39.635287 & -77.450635 & 296 & 157.6 \\
\hline \multirow{2}{*}{ LBH } & LBH.1 & 39.633224 & -77.449957 & 283 & $2,104.0$ \\
& LBH.2* & 39.631374 & -77.446842 & 282 & $2,145.3$ \\
\hline
\end{tabular}




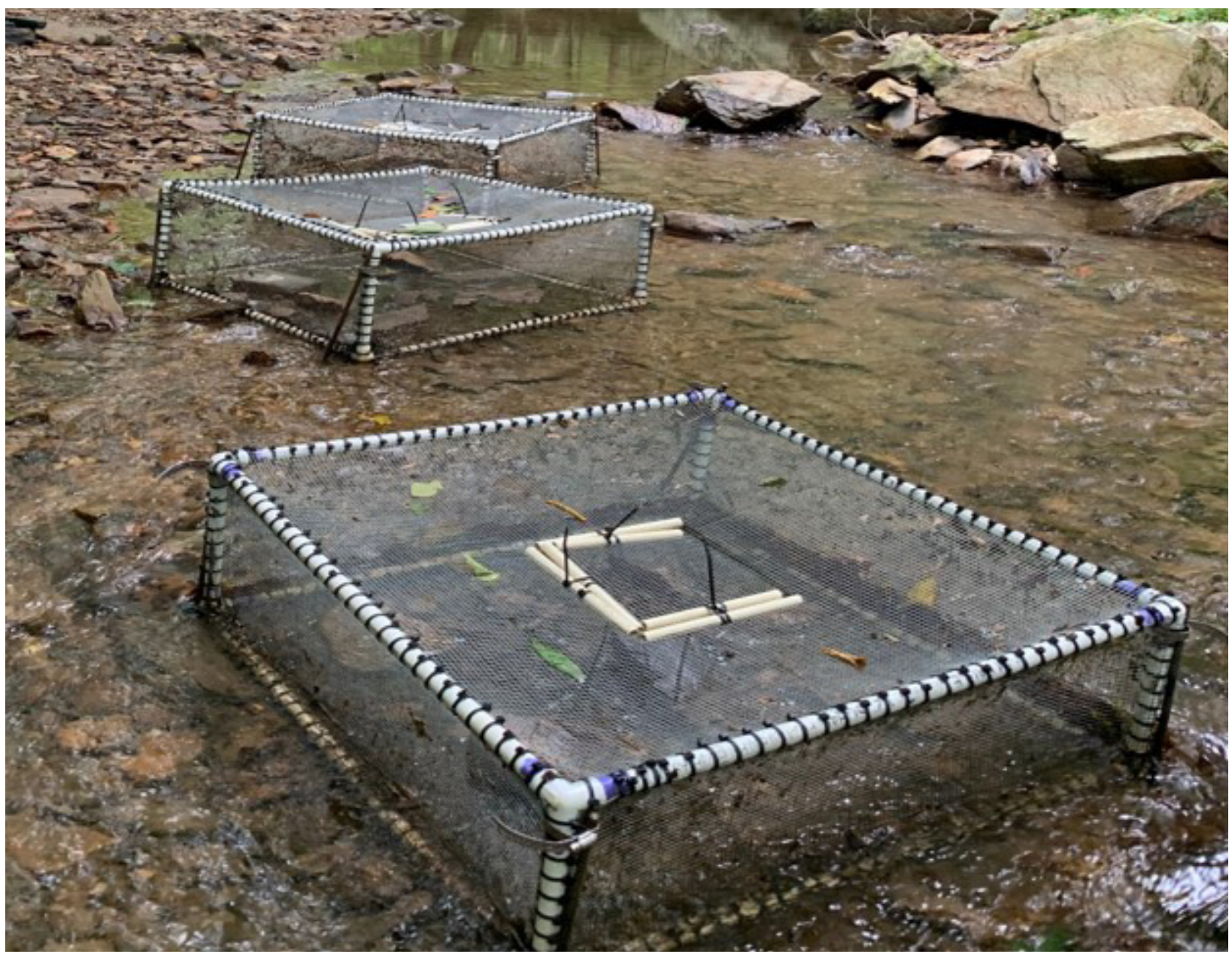

Figure 2. Example of experimental fish enclosure placement in Owens Creek (site OWC.1). Photograph by N.P. Hitt, U.S. Geological Survey.

\section{Statistical Analysis}

We evaluated individual growth rates with model selection techniques in a linear mixed-modeling framework. We compared a series of fitted models with all combinations of site-level covariates including elevation (a proxy for air temperature), upstream basin area (a proxy for habitat volume), and two summaries of water temperature: mean daily temperature (MDT) and accumulated degree-days above $20^{\circ} \mathrm{C}$ (DD20). Site-level covariates were treated as fixed effects in the linear models. We also included a random-intercept by cage in all models to account for possible effects of cage placement within a site or differences in density-dependent competition across cages. We scaled numeric covariates to a mean of zero and standard deviation of one (that is, $z$-score transformation) to facilitate comparisons. Elevation and upstream basin area were not significantly correlated among cage sites (Pearson's $r=$ $-0.40 ; p=0.25)$.
We compared candidate models using Akaike information criterion (AIC) scores (Burnham and Anderson, 2002) and evaluated the significance of covariates in top-performing models based on 95-percent confidence intervals generated from 1,000 bootstrapped samples. We used functions in R packages lme4 version 1.1-23 (Bates and others, 2015) and MuMIn version 1.43.17 (Barton, 2020) to fit and evaluate linear mixed-models. We estimated the coefficient of determination for each model with and without random effects (that is, conditional and marginal $R^{2}$, respectively) to evaluate the proportion of variance in growth explained by each component of the model (Nakagawa and Schielzeth, 2013). All statistical analysis and plotting was conducted in R version 3.6.3 (R Core Team, 2020). Stream temperature and fish growth data used in this analysis are available from Hitt and others (2020). 


\section{Results}

\section{Stream Temperature Assessment}

Observed stream temperatures ranged from $11.2{ }^{\circ} \mathrm{C}$ in Owens Creek (OWC.1) to $26.6^{\circ} \mathrm{C}$ in lower Big Hunting Creek (LBH.1) (table 2; fig. 3) Temperatures exhibited more temporal variation in Big Hunting Creek than elsewhere: a site (UBH.1) in upper Big Hunting Creek showed the largest range in observed temperatures $\left(13.6^{\circ} \mathrm{C}\right.$; table 2$)$, and a site (LBH.1) in lower Big Hunting Creek showed the largest standard deviation in observed hourly temperatures $\left(2.4^{\circ} \mathrm{C}\right.$; table 2$)$. Hourly temperatures within streams exhibited close correspondence across sites (appendix 1, figs. 1.1-1.4) and were highly correlated (Pearson's $r>0.99$ for all pairwise combinations).

Daily mean temperatures were significantly different among streams during the study period $(F=10.8, \mathrm{df}=3$, $p<0.0001$ ) with lower temperatures in Owens Creek than in upper or lower Big Hunting Creek (table 3). Moreover, daily mean temperatures in Owens Creek were consistently cooler than other streams during the study period (fig. 4). In contrast, lower and upper Big Hunting Creek alternated as the warmest sites (fig. 4), likely owing to effects of precipitation on discharge from Hunting Creek Lake, which separates the upper and lower Big Hunting Creek sites (fig. 1). Daily mean stream temperatures in Blue Blazes Creek generally showed an intermediate pattern between Owens Creek and Big Hunting Creek (fig. 4), but the maximum observed temperature in Blue Blazes Creek was only 1.1 degrees cooler than observed in upper Big Hunting Creek (table 2).

Grand-mean temperatures did not exceed the $20^{\circ} \mathrm{C}$ threshold for physiological stress in brook trout (table 2), but all sites exceeded this value for maximum temperatures (table 2) and daily mean temperatures (fig. 4). However, the accumulated time above $20^{\circ} \mathrm{C}$ (DD20) showed important differences among streams: DD20 was 10 times greater in upper Big Hunting Creek than Owens Creek and was 14 times greater in lower Big Hunting Creek than Owens Creek (table 2). Likewise, MWAT was below the $23.3^{\circ} \mathrm{C}$ threshold for brook trout occurrence in Owens Creek and Blue Blazes Creek but exceeded this threshold in upper and lower Big Hunting Creek sites (table 2).

\section{Fish Enclosure Experiment}

We observed 361 fish representing 7 taxonomic families and 8 species within 300-m of Owens Creek (table 4). The most abundant species was Blue Ridge sculpin (65 percent) followed by blacknose dace ( 21 percent). Brook trout composed approximately 4 percent of the total catch and included age-0 (young-of-year) fish as well as adult (age 1+) fish (table 4). Incidental inspection of brook trout gills showed no sign of Dermocystidium infection.

Pre-exposure histological analysis confirmed the absence of Dermocystidium infection in all sampled specimens held during the quarantine period (see Methods). The in situ exposure period encompassed 45 days (July 26 to September 9, 2019) during a period of time when sites in Big Hunting Creek were warmer than in Owens Creek or Blue Blazes Creek (fig. 3). A significant rainfall event during the exposure period appeared to increase temperatures in LBH owing to surface water runoff from Hunting Creek Lake. Histological analysis also detected myxozoan cysts in the muscle, ovary, and liver tissues from several specimens, and parasitic worms were observed in the lumen of the gut in several specimens. Myxozoan cysts and parasitic worms were detected in specimens from all streams, and there was no observable host response to these infections.

Post-exposure histological analysis detected no Dermocystidium infection in fish held in in situ enclosures. Fish growth rates (SGR) ranged from -0.088 in Blue Blazes Creek (BBC.1) to 0.559 in lower Big Hunting Creek (LBH.2) (table 5). Mean SGR was positive in all sites, but generally greater in Big Hunting Creek sites (UBH.2 and LBH.2) than

Table 2. Summary of hourly stream temperatures during the 100-day sample period (June 1, 2019, to September 9, 2019). The minimum, mean, maximum, standard deviation, and maximum weekly average temperature are expressed in degrees Celsius.

\begin{tabular}{|c|c|c|c|c|c|c|}
\hline Stream code & Site code & Minimum & Mean & Maximum & $\begin{array}{l}\text { Standard } \\
\text { deviation }\end{array}$ & $\begin{array}{c}\text { Maximum weekly } \\
\text { average temperature }\end{array}$ \\
\hline \multirow[t]{2}{*}{ OWC } & OWC.1 & 11.20 & 17.65 & 22.39 & 1.85 & 20.96 \\
\hline & OWC. 3 & 11.22 & 17.87 & 22.75 & 1.90 & 21.38 \\
\hline $\mathrm{UBH}$ & UBH.1 & 11.78 & 19.12 & 25.38 & 2.19 & 23.56 \\
\hline \multirow[t]{2}{*}{$\mathrm{BBC}$} & BBC.1 & 11.76 & 18.33 & 23.59 & 2.02 & 22.59 \\
\hline & BBC.2 & 11.64 & 18.61 & 24.27 & 2.11 & 23.07 \\
\hline \multirow[t]{2}{*}{ LBH } & LBH.1 & 13.86 & 19.38 & 26.57 & 2.38 & 24.58 \\
\hline & LBH.2 & 13.40 & 19.33 & 26.23 & 2.31 & 24.27 \\
\hline
\end{tabular}




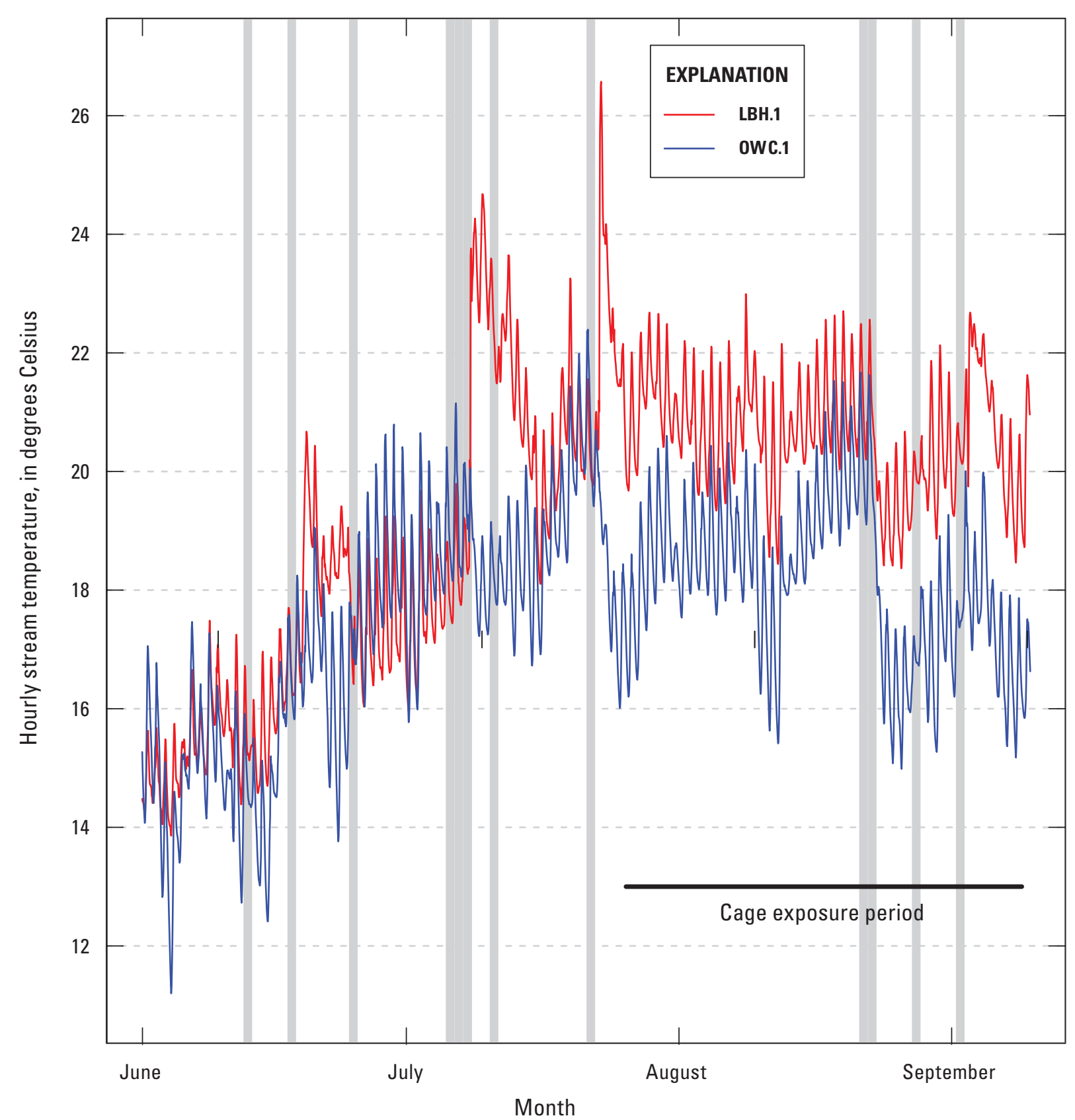

Figure 3. Hourly stream temperatures for the warmest site (LBH.1) and coolest site (OWC.1) during summer 2019 (100 days). Tick marks on the $x$-axis show the first day of each month. Site locations are mapped in figure 1. Grey vertical lines indicate significant rainfall events (see text).

elsewhere (table 5). For instance, mean sculpin growth in the control site where fish were initially collected (OWC.1) was approximately five times lower than observed in Big Hunting Creek sites (table 5).

Linear mixed models revealed stronger effects of temperature than other predictors on fish growth (table 6). Thermal summaries of DD20 and MDT were included in the top-performing models (that is, lowest AIC scores) (table 6), and bootstrapped 95-percent confidence intervals exceeded zero for each scaled parameter $(0.03-0.16$ and $0.02-0.15$, respectively) indicating a positive effect of water temperature on fish growth. In contrast, the next best model included an effect of upstream basin area (table 6), but this predictor was not significantly different from zero in bootstrapped 95 -percent confidence intervals $(-0.03-0.14)$. Thermal effects in the top performing models explained between 24 and 28 percent of the variation in sculpin growth $\left(R^{2}\right.$ marginal $)$, and with the inclusion of random effects these models each explained approximately 51 percent of the observed variation in sculpin growth $\left(R^{2}\right.$ conditional; table 6$)$. 
Table 3. Comparison of daily mean temperatures within Owens Creek (OWC), upper Big Hunting Creek (UBH), Blue Blazes Creek (BBC), and lower Big Hunting Creek (LBH). Pairwise differences between streams are shown as Tukey post-hoc comparisons from an ANOVA model with significant streamwise differences in daily mean stream temperatures during summer $2019(F=13.6, \mathrm{df}=3$, $p<0.0001)$. Pairwise differences with 95-percent confidence intervals excluding zero are indexed with *.

\begin{tabular}{lccc}
\hline \multicolumn{1}{c}{ Stream comparison } & Mean difference & $\begin{array}{c}\text { Lower 95-percent confidence } \\
\text { interval }\end{array}$ & $\begin{array}{c}\text { Upper 95-percent confidence } \\
\text { interval }\end{array}$ \\
\hline LBH-BBC* & 0.87 & 0.16 & 1.58 \\
OWC-BBC & -0.70 & -1.41 & 0.01 \\
UBH-BBC & 0.69 & -0.02 & 1.40 \\
OWC-LBH* & -1.57 & -2.28 & -0.86 \\
UBH-LBH & -0.18 & -0.89 & 0.53 \\
UBH-OWC* & 1.39 & 0.68 & 2.10 \\
\hline
\end{tabular}

\section{Discussion}

Native species conservation is a fundamental objective of the National Park system, and our study provides new inferences for stream fish conservation planning in CATO by linking observational and experimental research. We monitored stream temperatures and conducted a caged-fish experiment in CATO to assess fish growth and disease susceptibility during the summer of 2019 (100 days of temperature monitoring and 45 days of in-situ exposure for 33 fish). Our study demonstrated that (1) stream temperatures are significantly warmer in Big Hunting Creek (above and below Cunningham Falls) than in Owens Creek, (2) sculpin growth increased with temperature, and (3) Dermocystidium did not infect fish held in experimental enclosures in the study area. For these reasons we suggest that environmental conditions in upper Big Hunting Creek may be suitable for reintroduction of native Blue Ridge sculpin. Here we discuss our results in the context of prior research, and we provide recommendations for future research and conservation planning in the study area.

Observed stream temperatures in 2019 were largely consistent with prior surveys. As observed during summers of 2015 and 2016 (Hitt and others, 2017a), we found that Owens Creek was colder than Big Hunting Creek in 2019 (table 2 and table 3). We also found that mean stream temperatures in 2019 (table 2) were within the range of mean temperatures observed at the stream-level in 2015 and 2016 (Hitt and others, 2017a). Likewise, Big Hunting Creek sites showed the highest maximum temperatures within the study area in 2015 and 2016 (Hitt and others, 2017a) as well as 2019 (table 2). However, sites in Big Hunting Creek exceeded the thermal threshold for brook trout (MWAT $>23.3^{\circ} \mathrm{C}$; Wehrly and others, 2007) in 2019 (table 2), whereas they did not exceed this threshold in 2015 or 2016 (Hitt and others, 2017a). Thermal habitat therefore may be a limiting factor for brook trout conservation in Big Hunting Creek. Moreover, elevated temperatures may exacerbate competition with nonnative brown trout (Salmo trutta) (Hitt and others, 2017b), and this is the subject of an ongoing investigation by MD-DNR, USGS, and the National Park Service to evaluate brook trout responses to manual removal of brown trout in upper Big Hunting Creek.

We attribute elevated temperatures in upper Big Hunting Creek to pond runoff from outside CATO and elevated temperatures in lower Big Hunting Creek to runoff from Big Hunting Lake located within Cunningham Falls State Park. To the contrary, we cannot attribute elevated stream temperatures in upper Big Hunting Creek to the so-called blowdown section (that is, riparian disturbance from a storm in 2004) because a temperature gage located at the upstream extent of the blowdown section also showed elevated temperatures. Moreover, precipitation events had different effects in different streams. For instance, a significant rainfall event on July 21-22, 2019, increased temperatures in lower Big Hunting Creek but decreased temperatures in Owens Creek (fig. 3). Prior research also has shown cooling effects of precipitation on stream temperature (Merriam and others, 2017) and warming effects of runoff from upstream impoundments (Lessard and Hayes, 2003; Kelly and others, 2016).

The fish assemblage observed in Owens Creek during 2019 was very similar to prior surveys. For instance, the density of Blue Ridge sculpin was 83 fish/100 m in 2015 (Hitt and others, 2017a) and 78 fish/100 $\mathrm{m}$ in 2019 (table 4) even though the total amount of habitat sampled in Owens Creek was much greater in 2015 than 2019 (4,600 m and $300 \mathrm{~m}$, respectively). All eight species observed in 2019 were detected in Owens Creek in 2015 (Hitt and others, 2017a). However, two species were observed in 2015 but not 2019 (brown trout and Potomac sculpin [Cottus girardi]) probably because the sampling design in 2015 included areas further downstream than in 2019.

The fish enclosure experiment documented that shortterm exposure to site conditions did not cause Dermocystidium infection in sculpin. Although the pathological mechanisms and taxonomy of the Dermocystidium observed previously in the study area are not fully resolved (Blazer and others, 2016), our study provides experimental evidence that short-term exposure to site conditions does not necessarily yield infection in sculpin within the study area. Our use of summer conditions 


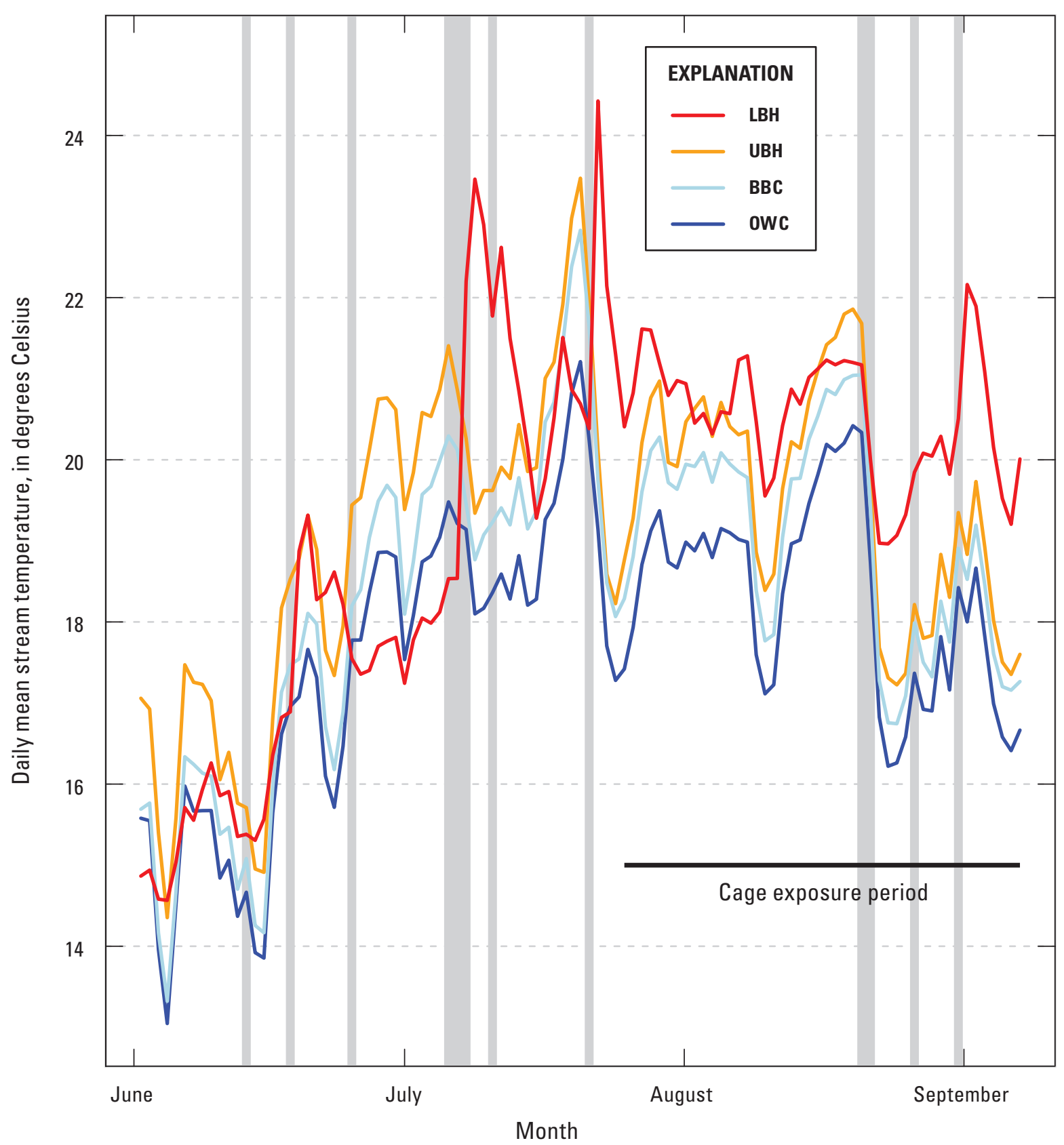

Figure 4. Daily mean stream temperatures averaged across sites within Owens Creek (OWC), upper Big Hunting Creek (UBH), Blue Blazes Creek (BBC), and lower Big Hunting Creek (LBH). Sites are mapped in figure 1. Grey vertical lines indicate significant rainfall events (see text).

for this experiment is useful because thermal stress is often associated with compromised immune system function, which may exacerbate pathogen and parasite infections (Marcogliese, 2001). However, we cannot reject the possibility that longterm exposure may yield infection in sculpin in upper Big Hunting Creek because Dermocystidium can become dormant as spores in substrate (Pekkarinen and Lotman, 2003; Gozlan and others, 2014) and its virulence may increase below approximately $16{ }^{\circ} \mathrm{C}$ (Allen and others, 1968), a temperature which was observed only on a few nights during the exposure period (appendix 1, figs. 1.1-1.4). Likewise, Mahboub and Shaheen (2020) observed higher rates of Dermocystidium infection in Nile tilapia (Oreochromis niloticus) during winter than summer.

The fish enclosure experiment also demonstrated that fish grew faster in warmer sites, including candidate reintroduction locations. Fish growth typically follows a curvilinear response to water temperature such that growth rates are optimized at some intermediate temperature (Lugert and others, 2016). Our results indicated that stream temperature was a stronger 
Table 4. Relative abundance of fish in three spatially consecutive 100-m sampling areas within Owens Creek. Backpack electrofishing proceeded in an upstream direction from OWC.3 (see fig. 1) on May 24, 2019, and June 7, 2019 (see text for details).

\begin{tabular}{|c|c|c|c|c|c|}
\hline Family & Scientific name & Common name & $\begin{array}{c}\text { Observed } \\
\text { abundance }\end{array}$ & $\begin{array}{l}\text { Proportional } \\
\text { abundance }\end{array}$ & $\begin{array}{l}\text { Fish density (num- } \\
\text { ber/100 meters) }\end{array}$ \\
\hline Catostomidae & Catostomus comersonii & White sucker & 8 & 0.022 & 2.7 \\
\hline \multirow[t]{2}{*}{ Leuciscidae } & Rhinichthys atratulus & Blacknose dace & 77 & 0.213 & 25.7 \\
\hline & Rhinichthys cataractae & Longnose dace & 13 & 0.036 & 4.3 \\
\hline Percidae & Etheostoma flabellare & Fantail darter & 5 & 0.014 & 1.7 \\
\hline \multirow[t]{2}{*}{ Salmonidae } & Salvelinus fontinalis & $\begin{array}{l}\text { Brook trout (young-of- } \\
\text { year) }\end{array}$ & 6 & 0.017 & 2.0 \\
\hline & & Brook trout (age $1+)$ & 9 & 0.025 & 3.0 \\
\hline
\end{tabular}

Table 5. Site-level summaries for fish growth and exposure temperatures for the caged-fish experiment. Sample size $(n)$ indicates the number of fish introduced in cages in each site. DD20 is the cumulative daily mean temperature above $20^{\circ} \mathrm{C}$ during the 45 -day exposure period. Mean daily water temperatures (MDT) are calculated from hourly data during the 45-day fish exposure period and are given in degrees Celsius. Sites are mapped in figure 1.

\begin{tabular}{|c|c|c|c|c|c|c|c|}
\hline \multirow[b]{2}{*}{ Site code } & \multirow[b]{2}{*}{$n$} & \multicolumn{4}{|c|}{ Specific growth rate } & \multicolumn{2}{|c|}{ Temperature } \\
\hline & & Minimum & Maximum & Mean & Standard deviation & MDT & DD20 \\
\hline OWC.3 & 8 & -0.058 & 0.160 & 0.054 & 0.076 & 18.4 & 1.9 \\
\hline UBH.3 & 6 & 0.000 & 0.289 & 0.157 & 0.106 & 19.5 & 16.1 \\
\hline BBC.1 & 6 & -0.088 & 0.207 & 0.028 & 0.130 & 18.9 & 4.1 \\
\hline
\end{tabular}

Table 6. Summary of fitted linear mixed models for specific growth rate from the caged fish experiment. All models included random intercepts by cage. Columns provide degrees of freedom (df), Akaike information criterion (AIC) scores, the relative difference in AIC score from the best-performing model $(\Delta \mathrm{AIC})$, and the proportion of variance explained by fixed effects $\left(\mathrm{R}^{2}\right.$ marginal $)$ and by fixed and random effects $\left(R^{2}\right.$ conditional $)$. Table 5 gives covariates for mean daily temperature (MDT) and degree-days (DD20), and table 1 gives covariates for elevation (ELE) and upstream basin size (UBA).

\begin{tabular}{|c|c|c|c|c|c|}
\hline Fixed effects & df & AIC & $\Delta \mathrm{AIC}$ & $\mathbf{R}_{\text {marginal }}$ & $\mathbf{R}^{2}$ conditional \\
\hline DD20 & 4 & -17.29 & 0.00 & 0.275 & 0.510 \\
\hline MDT & 4 & -16.38 & 0.91 & 0.236 & 0.514 \\
\hline ELE & 4 & -12.66 & 4.62 & 0.035 & 0.544 \\
\hline DD20 + ELE & 5 & -12.13 & 5.15 & 0.327 & 0.532 \\
\hline $\mathrm{MDT}+\mathrm{ELE}$ & 5 & -11.74 & 5.54 & 0.310 & 0.534 \\
\hline $\mathrm{MDT}+\mathrm{UBA}$ & 5 & -10.52 & 6.76 & 0.226 & 0.544 \\
\hline $\mathrm{ELE}+\mathrm{UBA}$ & 5 & -9.49 & 7.80 & 0.206 & 0.554 \\
\hline DD20 + ELE + UBA & 6 & -6.53 & 10.76 & 0.311 & 0.558 \\
\hline $\mathrm{MDT}+\mathrm{ELE}+\mathrm{UBA}$ & 6 & -5.93 & 11.36 & 0.298 & 0.561 \\
\hline
\end{tabular}


predictor of growth than other predictors (table 5 and table 6), which suggests that increased prey availability and foraging success accounted for the increased metabolic demands with elevated water temperatures in Big Hunting Creek. Moreover, although Big Hunting Creek was warmer than Owens Creek (table 3), none of the observed water temperatures reached the thermal threshold reported for a closely related species $(24.3$ ${ }^{\circ} \mathrm{C}$, mottled sculpin, Cottus bairdii) (Eaton and Scheller, 1996) at the daily or hourly time-step (fig. 3 and fig. 4). Our results therefore indicate that conditions in the study area are suitable for sculpin growth and survival.

Interpreting our growth experiment results requires consideration of the effects of enclosures on food availability. Using a similar design, Zimmerman and Vondracek (2006) showed that water flow rate decreases within such enclosures, and this can reduce the rate of incoming food for fish held in the enclosure. However, they found that sculpin growth increased with the size of macroinvertebrates in the drift and prey size was not different between enclosures and adjacent riffle habitats (Zimmerman and Vondracek, 2006). Although we did not quantify macroinvertebrate abundance or biomass in this study, our results indicate that the biomass of incoming prey was enough to account for increased metabolic demands associated with elevated temperatures in Big Hunting Creek. Our use of enclosures also restricted the potential for fish movement. Although sculpin can move relatively long distances (for example, $>1.7$ kilometers in 75 days for Potomac sculpin, Cottus girardi; Hudy and Shiflet, 2009), mottled sculpin generally show highly restricted movement patterns (for example, $1.3 \mathrm{~m}$ median movement distance over 45 days; Petty and Grossman, 2004) consistent with the size of our experimental enclosures.

Collectively, our results may suggest that environmental conditions in upper Big Hunting Creek are suitable for restoration of native Blue Ridge sculpin. To this end, a reintroduction and monitoring plan could be developed to include analysis of minimum viable population size for reintroduction, the capacity for Owens Creek to serve as a donor population, histopathological analysis of fish before and after reintroduction, and fish growth rates and recruitment in upper Big Hunting Creek. Results from this further analysis could lead to expanding sportfishing opportunities by increasing the forage base for brook trout. We believe this could be a unique opportunity for native species restoration in a National Park that combines native species conservation with enhanced sportfishing opportunities.

\section{References Cited}

Adams, S., and Schmetterling, D., 2007, Freshwater sculpins - Phylogenetics to ecology: Transactions of the American Fisheries Society, v. 136, p. 1736-1741. [Also available at https://doi.org/10.1577/T07-023.1].

Allen, R.L., Meekin, T.K., Pauley, G.B., and Fujihara, M.P., 1968, Mortality among Chinook salmon associated with the fungus Dermocystidium: Journal of the Fisheries Research Board of Canada, v. 25, p. 2467-2475. [Also available at https://doi.org/10.1139/f68-215].

American Fisheries Society-Fish Health Section, 2016, FHS blue book-Suggested procedures for the detection and identification of certain finfish and shellfish pathogens: American Fisheries Society, Bethesda, Maryland, accessed August 2020 at http://afs-fhs.org/bluebook/bluebookindex.php.

Barton, K., 2020, MuMIn-Multi-model inference (ver. 1.43.17): The Comprehensive R Archive Network web page, accessed August 2020 at https://CRAN.R-project.org/ package $=$ MuMIn .

Bates, D., Mächler, M., Bolker, B., and Walker, S., 2015, Fitting linear mixed-effects models using lme4: Journal of Statistical Software, v. 67, no. 1, p. 1-48. [Also available at https://doi.org/10.18637/jss.v067.i01].

Blazer, V.S., Hitt, N.P., Snyder, C.D., and Snook, E., 2016, Dermocystidium sp. infection in Blue Ridge Sculpin Cottus caeruleomentum captured in Maryland, USA: Journal of Aquatic Animal Health, v. 28, p. 143-149. [Also available at https://doi.org/10.1080/08997659.2016.1159622].

Burnham, K.P., and Anderson, D.R., 2002, Model selection and multimodel inference-A practical informationtheoretic approach (2d ed.): New York, SpringerVerlag, $488 \mathrm{p}$.

Cook, J.T., McNiven, M.A., Richardson, G.F., and Sutterlin, A.M., 2000, Growth rate, body composition and feed digestibility / conversion of growth-enhanced transgenic Atlantic salmon: Aquaculture (Amsterdam, Netherlands), v. 188, p. 15-32. [Also available at https://doi.org/10.1016/ S0044-8486(00)00331-8].

Eaton, J.G., and Scheller, R.M., 1996, Effects of climate warming on fish thermal habitat in streams of the United States: Limnology and Oceanography, v. 41, p. 1109-1115. [Also available at https://doi.org/10.4319/1o.1996.41.5.1109].

Gozlan, R.E., Marshall, W.L., Liije, O., Jessop, C.N., Gleason, F.H., and Andreou, D., 2014, Current ecological understanding of fungal-like pathogens of fish-What lies beneath?: Frontiers in Microbiology, v. 5, p. 1-16. [Also available at https://doi.org/10.3389/fmicb.2014.00062]. 
Hitt, N.P., Snyder, C.D., Snook, E.L., Johnson, Z.C., and Morgan, M.J., 2017a, Forecasting stream habitat and brook trout responses to climate change in Catoctin Mountain Park: U.S. Geological Survey, Final Report for National Park Service, Catoctin Mountain Park, 51 p., accessed August 2020 at https://pubs.er.usgs.gov/publication/ 70194729 .

Hitt, N.P., Snook, E.L., and Massie, D.L., 2017b, Brook trout use of thermal refugia and foraging habitat influenced by brown trout: Canadian Journal of Fisheries and Aquatic Sciences, v. 74, p. 406-418. [Also available at https://doi.org/10.1139/cjfas-2016-0255].

Hitt, N.P., Kessler, K., Rogers, K., Macmillan, H., and Walsh, H., 2020, Stream temperature and sculpin growth data collected from Catoctin Mountain Park in 2019: U.S. Geological Survey data release, https://doi.org/10.5066/ P950A13P.

Hudy, M., and Shiflet, J., 2009, Movement and recolonization of Potomac sculpin in a Virginia stream: North American Journal of Fisheries Management, v. 29, p. 196-204. [Also available at https://doi.org/10.1577/M07-101.1].

Karvonen, A., Rintamäki, P., Jokela, J., and Valtonen, E.T., 2010, Increasing water temperature and disease risks in aquatic systems - Climate change increases the risk of some, but not all, diseases: International Journal for Parasitology, v. 40, no. 13, p. 1483-1488. [Also available at https://doi.org/10.1016/j.ijpara.2010.04.015].

Kelly, B., Smokorowski, K.E., and Power, M., 2016, Downstream effects of hydroelectric dam operation on thermal habitat use by brook trout (Salvelinus fontinalis) and slimy sculpin (Cottus cognatus): Ecology Freshwater Fish, v. 26, p. 552-562. [Also available at https://doi.org/10.1111/ eff.12299].

Kinzinger, A.P., Raesly, R.L., and Neely, D.A., 2000, New species of Cottus (Teleostei-Cottidae) from the middle Atlantic eastern United States: Copeia, v. 2000, p. 1007-1018. [Also available at http://doi.org/10.1643/00458511(2000)000[1007:nsoctc]2.0.co;2].

Kocan, R., Herberger, P., Sanders, G., and Winton, J., 2009, Effects of temperature on disease progression and swimming stamina in Ichthyophonus-infected rainbow trout, Oncorhynchus mykiss (Walbaum): Journal of Fish Diseases, v. 32, p. 835-843. [Also available at https://doi.org/10.1111/ j.1365-2761.2009.01059.x].

Lessard, J.L., and Hayes, D.B., 2003, Effects of elevated water temperature on fish and macroinvertebrate communities below small dams: River Research and Applications, v. 19, p. 721-732. [Also available at https://doi.org/10.1002/ rra.713].
Lugert, V., Thaller, G., Tetens, J., Schulz, C., and Krieter, J., 2016, A review on fish growth calculation-Multiple functions in fish production and their specific application: Reviews in Aquaculture, v. 8, p. 30-42. [Also available at https://doi.org/10.1111/raq.12071].

Luna, L., 1992, Histopathologic methods and color atlas of special stains and tissue artifacts: Gaithersburg, Maryland, American Histolabs, 767 p.

Mahboub, H.H., and Shaheen, A., 2020, Prevalence, diagnosis and experimental challenge of Dermocystidium sp. infection in Nile tilapia (Oreochromis niloticus) in Egypt: Aquaculture (Amsterdam, Netherlands), v. 516, p. 734556. [Also available at https://doi.org/10.1016/ j.aquaculture.2019.734556].

Marcogliese, D.J., 2001, Implications of climate change for parasitism of animals in the aquatic environment: Canadian Journal of Zoology, v. 79, p. 1331-1352. [Also available at https://doi.org/10.1139/z01-067].

Meredith, C.S., Budy, P., and Thiede, G.P., 2014, Predation on native sculpin by exotic brown trout exceeds that by native cutthroat trout within a mountain watershed (Logan, UT, USA): Ecology Freshwater Fish, v. 24, p. 133-147. [Also available at https://doi.org/10.1111/eff.12134].

Merriam, E.R., Fernandez, R., Petty, J.T., and Zegre, N., 2017, Can brook trout survive climate change in large rivers? If it rains: The Science of the Total Environment, v. 607-608, p. 1225-1236. [Also available at https://doi.org/10.1016/ j.scitotenv.2017.07.049].

Nakagawa, S., and Schielzeth, H., 2013, A general and simple method for obtaining R-squared from generalized linear mixed-effects models: Methods in Ecology and Evolution, v. 4, p. 133-142. [Also available at https://doi.org/10.1111/ j.2041-210x.2012.00261.x].

Pekkarinen, M., and Lotman, K., 2003, Occurrence and life cycles of Dermocystidium species (Mesomycetozoa) in the perch (Perca fluviatilis) and ruff (Gymnocephalus cernuus) (Pisces-Perciformes) in Finland and Estonia: Journal of Natural History, v. 47, p. 1155-1172. [Also available at https://doi.org/10.1080/00222930110120999].

Petty, J.T., and Grossman, G.D., 2004, Restricted movement by mottled sculpin (Pisces - Cottidae) in a southern Appalachian stream: Freshwater Biology, v. 49, p. 631-64. [Also available at https://doi.org/10.1111/j.13652427.2004.01216.x].

Reynolds, J.B., and Kolz, A.L., 2012, Electrofishing, in Zale, A.V., Parrish, D.L., and Sutton, T.M., eds., Fisheries techniques ( $3 d$ ed.): Bethesda, Md., American Fisheries Society, p. 305-361. 
R Core Team, 2020, R-A language and environment for statistical computing: Vienna, Austria, R Foundation for Statistical Computing, accessed August 2020 at https://www.R-project.org/.

Rowley, J.J., Gleason, F.H., Andreou, D., Marshall, W.L., Lilje, O., and Gozlan, R., 2013, Impacts of mesomycetozoean parasites on amphibian and freshwater fish populations: Fungal Biology Reviews, v. 27, p. 100-111. [Also available at https://doi.org/10.1016/j.fbr.2013.09.002].

Snyder, C.D., Hitt, N.P., and Young, J.A., 2015, Accounting for the influence of groundwater on thermal sensitivity of headwater streams to climate change: Ecological Applications, v. 25, p. 1397-1419. [Also available at https://doi.org/10.1890/14-1354.1].
Wehrly, K.E., Wang, L., and Mitro, M., 2007, Field-based estimates of thermal tolerance limits for trout-Incorporating exposure time and temperature fluctuation: Transactions of the American Fisheries Society, v. 136, p. 365-374. [Also available at https://doi.org/10.1577/T06-163.1].

Zimmerman, J.H.K., and Vondracek, B., 2006, Effects of stream enclosures on drifting invertebrates and fish growth: Journal of the North American Benthological Society, v. 25 , no. 2 , p. 453-464. [Also available at https://doi. org/10.1899/0887-3593(2006)25[453:eoseod]2.0.co;2]. 


\section{Appendix 1 Hourly Stream Temperature Plots}

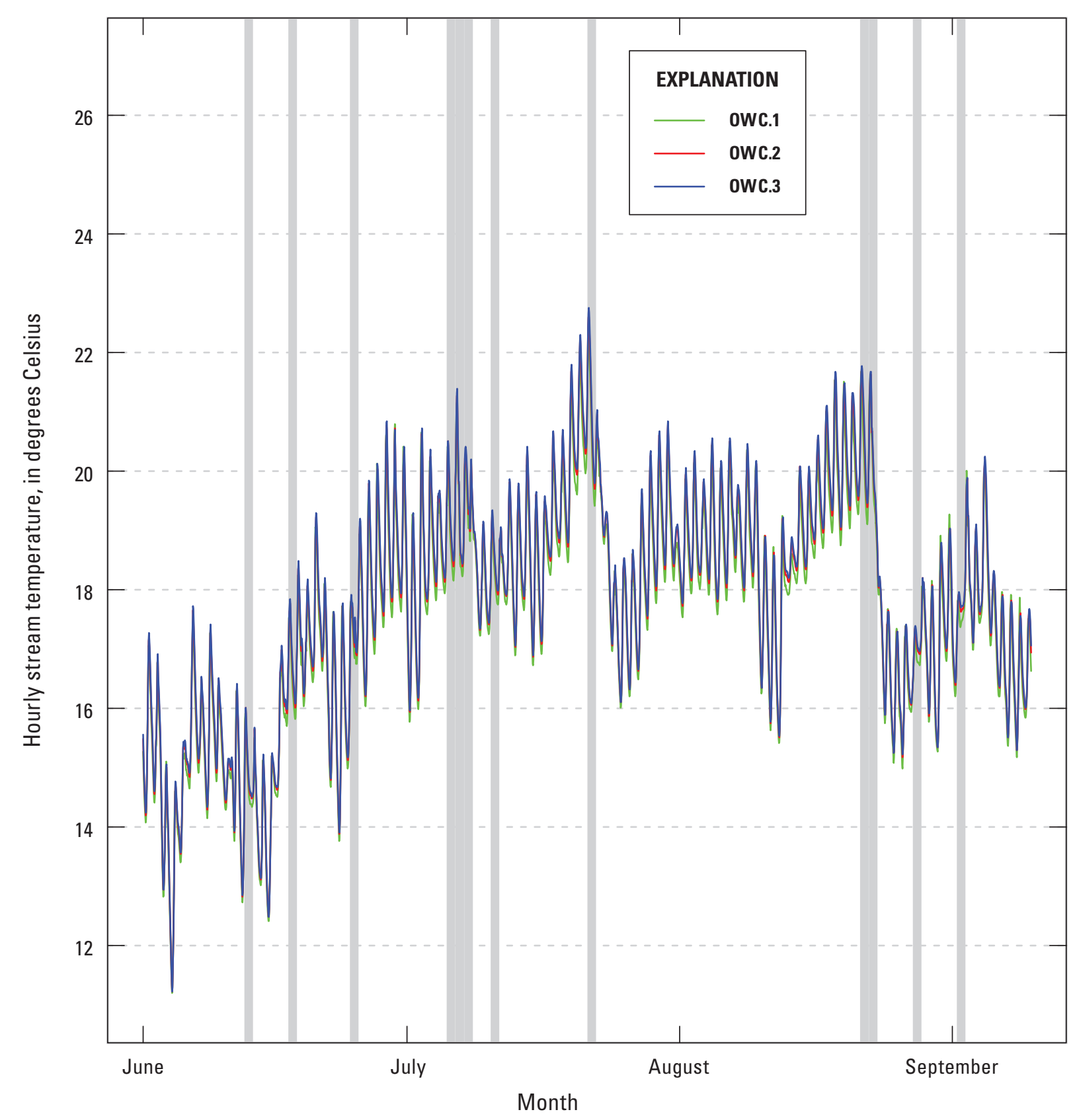

Figure 1.1. Hourly temperature plots during summer 2019 (100 days) in Owens Creek. Tick marks on the x-axis show the first day of each month. Site locations are mapped in figure 1 and site codes are given in table 1. Grey vertical lines indicate significant rainfall events (see text for methods). 


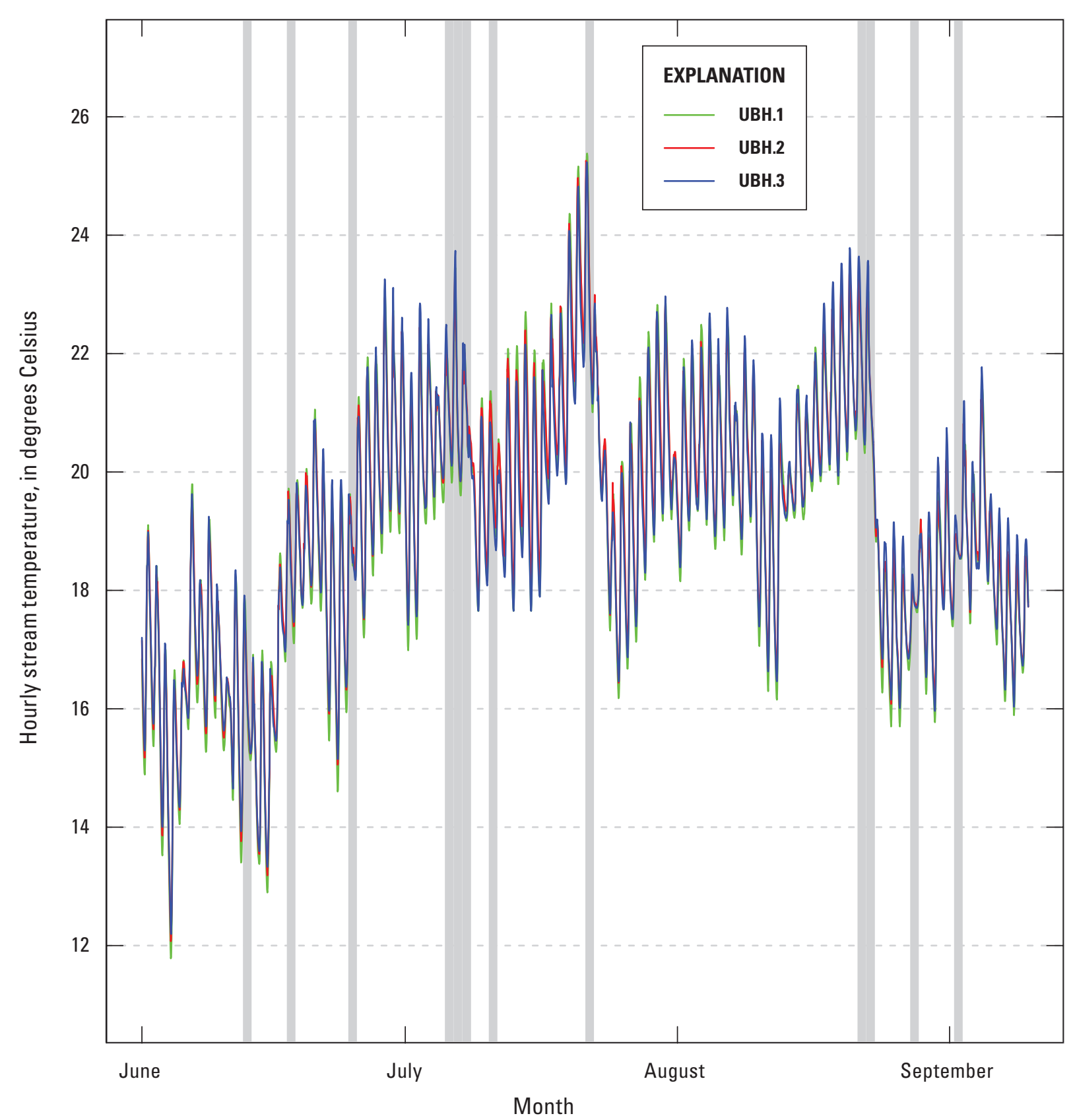

Figure 1.2. Hourly temperature plots during summer 2019 (100 days) in upper Big Hunting Creek. Tick marks on the $x$-axis show the first day of each month. Site locations are mapped in figure 1 and site codes are given in table 1. Grey vertical lines indicate significant rainfall events (see text for methods). 


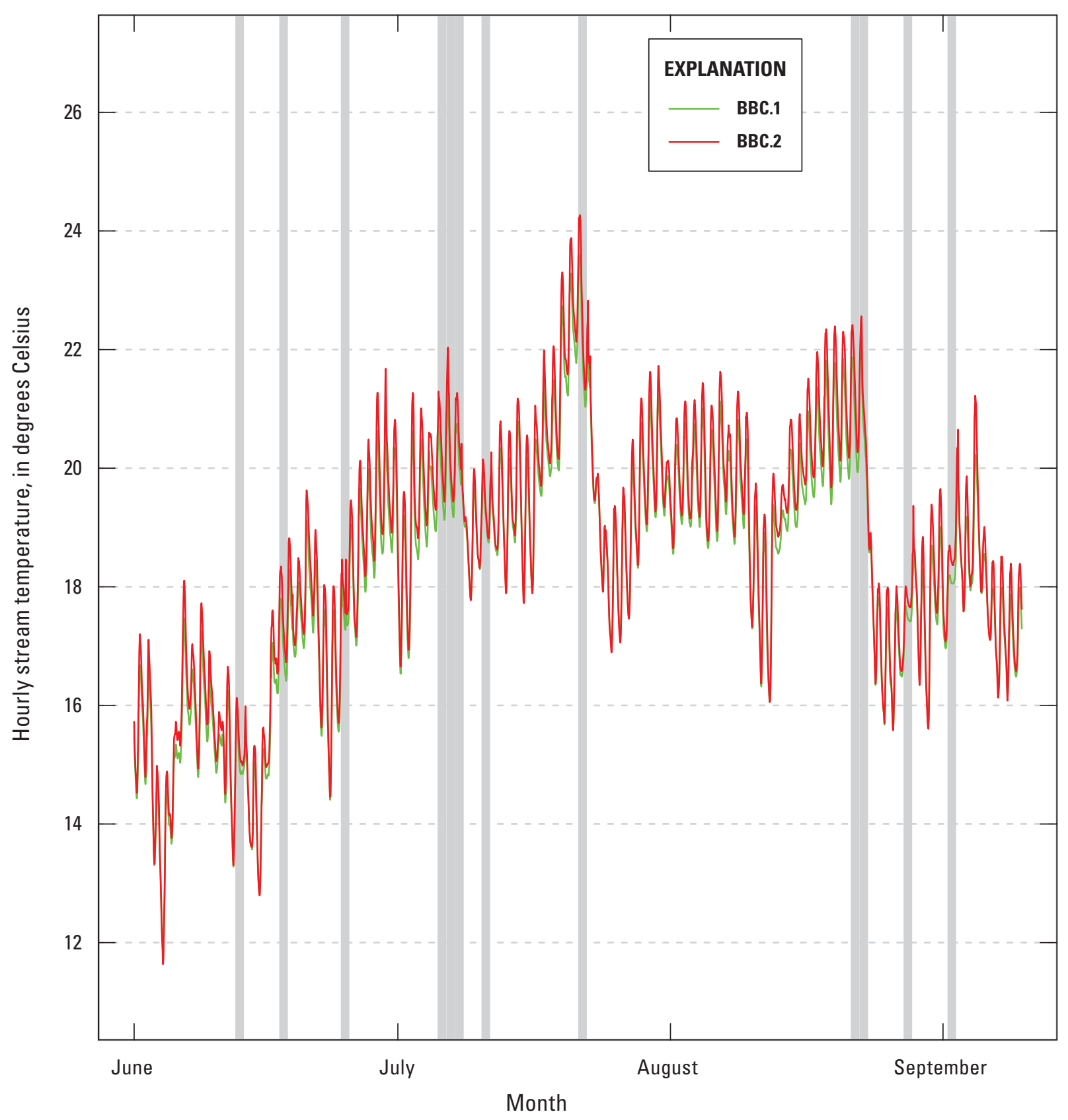

Figure 1.3. Hourly temperature plots during summer 2019 (100 days) in Blue Blazes Creek. Tick marks on the $\mathrm{x}$-axis show the first day of each month. Site locations are mapped in figure 1 and site codes are given in table 1. Grey vertical lines indicate significant rainfall events (see text for methods). 


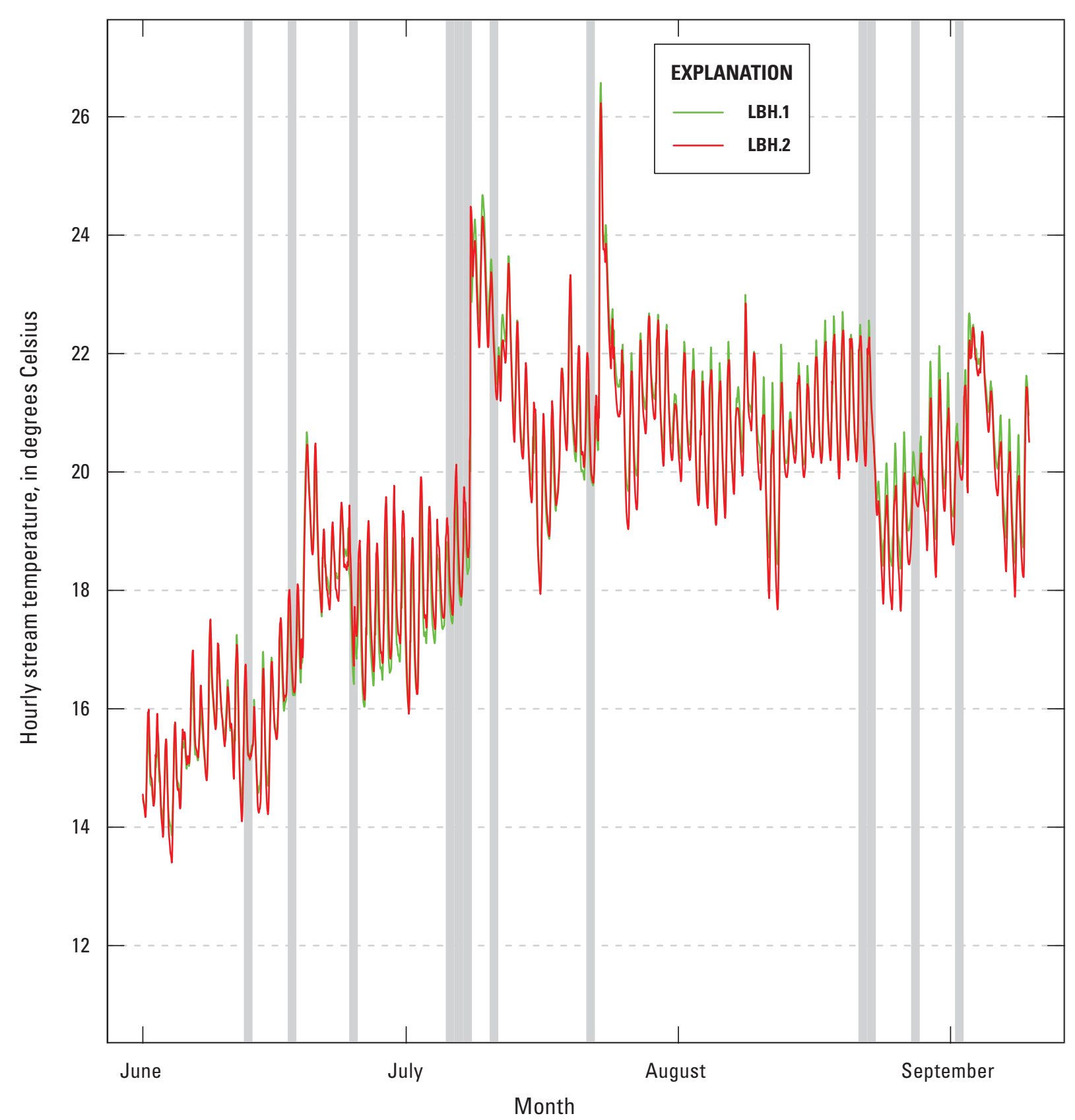

Figure 1.4. Hourly temperature plots during summer 2019 (100 days) in lower Big Hunting Creek. Tick marks on the $x$-axis show the first day of each month. Site locations are mapped in figure 1 and site codes are given in table 1. Grey vertical lines indicate significant rainfall events (see text for methods). 

For additional information, contact:

Director, Leetown Science Center

U.S. Geological Survey

11649 Leetown Road

Kearneysville, WV 25430

Or visit our website at https://usgs.gov/centers/lsc

Publishing support provided by the West Trenton Publishing

Service Center 


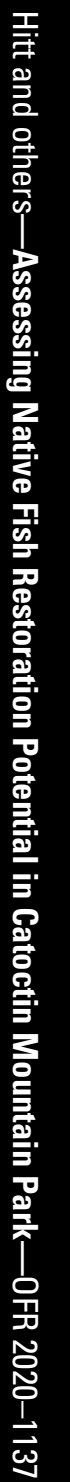

